\title{
Cost recovery trumps concerns about conflicted interest
}

A

lthough there's widespread variation in the policies that Canadian medical schools have toward pharmaceutical and medical devices industry handouts for medical education and in some cases, seemingly no policies at all, administrators say there is no need for restrictive guidelines like those recently adopted in the United States because the level of abuse isn't as severe north of the 49th parallel.

There's little justification for following America's lead by limiting industry support for continuing medical education services, or prohibiting financial payments, travel junkets and other goodies from industry to physicians, faculty, residents and students at medical schools and teaching hospitals, the administrators say.

Such subsidies and handouts are "not of the [same] order of magnitude" in Canada as in the United States, says Dr. Gavin Stuart, dean of medicine at the University of British Columbia, which appears to have the most restrictive industry handouts policy of the nation's 17 medical schools in that it caps financial payments at $20 \%$ of a faculty member's salary.

There's little political pressure, internal or external, to adopt stricter policies like those approved in June 2008 by the Association of American Medical College's executive-council, adds Queen's University Senior Associate Dean (Medical Education) Dr. Lewis Tomalty. "My sense is that we don't see abuses in the system so that we're comfortable where we are at."

Furthermore, Canadian medical schools would be resentful if the Association of Faculties of Medicine of Canada adopted a similar "top-down" approach, adds Dr. David McKnight, associate dean of equity and professionalism at the University of Toronto medical department. "If you impose things on people that they resent, they look for ways around them. If you can get a consensus as to what is a reasonable limitation, then it works better."

"Each university likes to keep its individuality," he adds.

By contrast, concerns that industry handouts are influencing therapeutic decisions and severely compromising the medical profession's reputation prompted the American association to formally adopt wide-ranging guidelines recommended by an internal Task Force on Industry Funding of Medical Education (CMAJ 2008;178[13]:16512). Several American institutions, including Yale and Stanford, have already moved to ban industry goodies.

The American Medical Association, meanwhile, deflected a proposal by its events, like speaker's bureaus, other than an obligation on the part of the faculty member to "ensure that the representation of their involvement does not confuse participation with endorsement of a particular product or enterprise."

Many schools indicated their faculties are now primarily guided by the recently revised Canadian Medical Association's guidelines for physicians in interactions with industry

\section{UBC guidelines are "fairly robust" Dean Dr. Gavin Stuart}

Council on Ethical and Judicial Affairs to entirely eliminate industry funding from medical education. The proposal was prevented from reaching the floor of the Association's annual general meeting in June when its Reference Committee sent the matter back to the Council for further input from stakeholders.

In general, Canadian medical schools appear similarly loathe to adopt anything like a prohibition on handouts, primarily because they now rely entirely on registration fees or industry subsidies to pay for continuing medical education programs. As Tomalty says, "we're all cost recovery."

Administrators at several other schools, speaking on condition of anonymity, said they simply "could not afford" to wean themselves of industry monies for continuing medical education, or wouldn't dare to do so, for fear of a physician backlash. "Have you ever tried to separate a doctor from the income to which he feels entitled?" asked one Ontario administrator.

Other institutions flatly refused to even disclose whether they have policies governing industry handouts or like McGill University and the University of Ottawa, indicated only that they are in the midst of reviews.

Still others, like the University of Western Ontario, offer written guidelines to their faculty, oft-times of a very general nature. Western's guidelines, for example, say there's no restriction on participation in industry-organized (policybase.cma.ca), which essentially say that "significant" gifts from industry should be declined.

"But the CMA guidelines didn't go as far as many of us wanted them to go," Tomalty notes, adding that there's also a significant nationwide variation in the extent to which institutions actually monitor, and audit, the activities of their faculty.

The Canadian administrators are also universally agreed that the level of industry handouts to Canadian physicians, and industry support for education programs, pales in comparison to the financial handouts received by Americans, which the Association of American Medical Colleges estimates are in the billions of dollars annually.

An Association of Faculties of Medicine of Canada survey conducted earlier this year indicated that about 20\%-30\% of continuing education budgets come from industry sponsorship, Tomalty says.

Overall, UBC's guidelines appear the most rigorous, requiring annual disclosure and approval by senior administrators. No faculty member is entitled to spend more than 52 days per year or earn more than $20 \%$ of their salary through external activities like speaker's bureaus. "It's a fairly robust system," Stuart says, adding that there seems to be a general consensus among deans across the nation "that this is the direction that one has to go."

Anything in the way of formal guidelines don't seem imminent, al- 
though Dalhousie University Assistant Director of Finance and Administration for CME Dr. Eileen MacDougall says the Association of Faculties of Medicine of Canada working group on continuing medical education will likely review the issue of industry handouts in the wake of the American crackdown to see if there's an inclination to develop a consensus, national approach.

Even if guidelines were developed, there'd still be a problem of enforcement, adds University of Alberta Dean of Medicine Dr. Tom Marrie. "The system is based on trust," he says. "I would favour a system wherein industry pay- ments to physicians are directed to a fund to provide support for health care in developing countries and funds to allow medical students to obtain an experience in such countries." - Wayne Kondro, CMAJ

DOI:10.1503/cmaj.081008

\section{Ranking solutions to}

\section{global problems}

$\mathrm{W}$ hat do you get when you ask 8 economists, including 5 Nobel Prize winners, to rank solutions to 10 global problems, if they had $\$ 75$ billion at their disposal? Eight different lists?

Not according to Bjorn Lomborg, a Danish business professor and author of the controversial book The Skeptical Environmentalist. The end product, he says, is a perfect cost-benefit analysis for improving the state of the planet.

Lomborg organizes the Copenhagen Consensus, a project founded in 2002 to find cost-effective ways of advancing global welfare. The 2008 edition drew a panel of 8 renowned economists to Denmark, where they spent a week analyzing proposals for addressing 10 global challenges (Box 1). After considering the costs and benefits of the solutions, the panel ranked them according to desirability, awarding top spot to a proposal to combat malnutrition by supplying micronutrients to undernourished children.

It would cost $\$ 60$ million a year to provide vitamin A capsules and zinc supplements to 140 million children in sub-Saharan Africa and South Asia, according to Sue Horton, vice-president (academics) at Wilfred Laurier University, who presented the top proposal. The economic benefits from lower mortality and better health would total $\$ 1$ billion, says Horton.

Five of the top 6 positions went to health initiatives. Using a cost-benefit analysis may be an effective way to improve global health, Horton says. "It's one thing to feel good about deworming children, but if at the same time you can show that you can save money in your education system or health system, those are strong arguments."

\section{Box 1: Getting the best bang for the world's buck}

The 2008 Copenhagen Consensus invited 8 economists to rank order 30 solutions to 10 global challenges, namely, air pollution, conflicts, diseases, education, global warming, malnutrition and hunger, sanitation and water, subsidies and trade barriers, terrorism, women and development. In descending order of desirability, their cost-benefit recommendations were:

1. Micronutrient supplements for children

2. The Doha development agenda

3. Micronutrient fortification

4. Expanded immunization coverage for children

5. Biofortification

6. Deworming and other nutrition programs at school

7. Lowering the price of schooling

8. Increase and improve girls' schooling

9. Community-based nutrition promotion

10. Provide support for women's reproductive role

11. Heart attack acute management

12. Malaria prevention and treatment

13. Tuberculosiscase finding and treatment

14. $R \& D$ in low-carbon energy technologies

15. Bio-sand filters for household water treatment

16. Rural water supply

17. Conditional cash transfers

18. Peace-keeping in post-conflict situations

19. HIV combination prevention

20. Total sanitation campaign

21. Improving surgical capacity at district hospital level

22. Microfinance

23. Improved stove intervention

24. Large, multipurpose dam in Africa

25. Inspection and maintenance of diesel vehicles

26. Low sulfur diesel for urban road vehicles

27. Diesel vehicle particulate control technology

28. Tobacco tax

29. $R \& D$ and mitigation

30. Mitigation only

Canada Research Chair of Health and Development Dr. Prabhat Jha, who heads the University of Toronto's Centre for Global Health Research, gave the session a mixed review. "I don't agree with all the conclusions, but it's an interesting exercise in getting different groups to see what are the best bets for the world."

Prabhat hopes the project raises awareness of 3 causes he presented: raising tobacco taxes, providing low-cost drugs for heart attack victims, and improving surgical capacity at district hospitals in developing nations.
The panel should have more strongly stressed the importance of research and might have investigated how large countries allocate their foreign aid, he adds. "If you're shopping for the world and you're going down an aisle and looking for things to buy that will give the most benefits, you have to remember those products were placed on the shelf because of research and knowledge institutions. The Copenhagen Consensus didn't quite capture that." - Roger Collier, CMAJ 